WISSENSCHAFTSZENTRUM BERLIN FÜR SOZIALFORSCHUNG

SOCIAL SCIENCE RESEARCH CENTER BERLIN

Richard Deeg

\title{
Complementarity and Institutional Change: How Useful a Concept?
}

Temple University, Philadelphia

SP II $2005-21$

December 2005

ISSN Nr. $0722-6748$

Research Area Markets and Politics

Research Group

Institutions, States, Markets
Forschungsschwerpunkt Märkte und Politik

Forschungsgruppe

Institutionen, Staaten, Märkte 
Zitierweise/Citation:

Richard Deeg, Complementarity and Institutional Change: How Useful a Concept?, Discussion Paper SP II 2005 - 21, Wissenschaftszentrum Berlin, 2005.

Wissenschaftszentrum Berlin für Sozialforschung gGmbH, Reichpietschufer 50, 10785 Berlin, Germany, Tel. (030) 25491 - 0 Internet: www.wz-berlin.de 


\title{
ABSTRACT
}

\section{Complementarity and Institutional Change: How Useful a Concept?}

\author{
by Richard Deeg
}

The concept of institutional complementarity - i.e. the idea that the co-existence of two or more institutions enhances the functioning of each - is increasingly used to explain why institutions are resistant to change and why introducing new institutions into a system often leads to unintended consequences or failure to achieve the intended objective. While the concept is appealing and intuitive, in reality its utility for explaining change is less than straightforward. This paper utilizes examples from comparative political economy to, first, unpack and delineate the concept and address the issue of how to measure the strength or 'binding force' of complementarities. Second, it assesses the utility of the concept for explaining institutional change. It is suggested that one's view of the methods and utility of measuring complementarity will hinge importantly on one's general theory of institutions and institutional change. In the end, while institutional complementarities are significant, assessing their causal effect on institutional change is difficult and ambiguous in most instances. A better understanding requires that we embed complementarities within a more general theory of institutional change which takes a broader view of the ways in which institutions interconnect and change.

Keywords: Institutions, Complementarities, Political Economy, Varieties of Capitalism JEL Classification: L86, G30 
Komplementarität und institutioneller Wandel: Wie brauchbar ist das Konzept?

Das Konzept der institutionellen Komplementarität - d.h. die Idee, dass zwei oder mehr Institutionen sich gegenseitig stützen und ihre Funktionsfähigkeit erhöhen - gilt mehr und mehr als Erklärung dafür, dass Institutionen gegen Veränderungen resistent sind und das Einführen neuer Institutionen in ein bestehendes System oft unerwartete Konsequenzen oder nicht darin erfolgreich sind, das gewünschte Ziel zu erreichen. Obwohl das Konzept attraktiv und intuitiv ist, ist sein Erklärungsnutzen nicht offensichtlich. In diesem Aufsatz werden Beispiele aus der vergleichenden politischen Ökonomie verwendet, um zunächst den Inhalt des Konzeptes zu umschreiben und die Frage zu stellen, wie die Stärke bzw. „Bindungskraft“ von Komplementaritäten zu messen sind. Dann bewertet er den Nutzen des Konzeptes zur Erklärung von institutionellem Wandel. Dabei ist darauf hinzuweisen, dass es stark vom Hintergrund des Betrachters, seiner allgemeinen Theorie von Institutionen und institutionellem Wandel, abhängt, welchen Blickwinkel er in Bezug auf die Einschätzung der Methoden und des Nutzen der Komplementaritätsmessung einnimmt. Abschließend stellt sich heraus, dass institutionelle Komplementaritäten wichtig sind, es aber in den meisten Fällen schwierig und unklar bleibt, ihren kausalen Effekt auf institutionellen Wandel zu bewerten. Zum besseren Verständnis ist es notwendig, dass das Konzept der Komplementaritäten in eine allgemeine Theorie des institutionellen Wandels eingebettet wird, die eine breitere Sicht über die Art und Weise zulässt, wie Institutionen untereinander verbunden sind und sich verändern. 
The concept of complementarity has rapidly gained significance within institutionalist theories. The core idea of complementarity is that the coexistence (within a given system) of two or more institutions mutually enhances the performance contribution of each individual institution - in essence, that the whole is more than the sum of its parts. The concept has been applied across a wide range of institutional spheres and levels, from the macro economy (Franzese 2001) to individual firms (Milgrom and Roberts 1995), from welfare regimes (Bettio and Plantenga 2004) to policing (Den Boer 2002). The concept of complementarity is central to any conception of system. Complementarity is also increasingly used to explain why institutions - and the actors who support them - are resistant to change (see Pierson 2004; North 1991, 2004) and also why introducing new institutions into a system often leads to unintended consequences or failure to achieve the intended objective. But institutional change does happen and, logically, if complementarities exist, then the process of change must be shaped in some way by them. Thus the ultimate objective of this paper is to analyze the utility of the concept of complementarity for understanding change - not just stasis.

The empirical references in this paper are to the role of institutional complementarities in constituting capitalist systems and in shaping their recent institutional change, though much of the discussion is relevant to institutional analysis in general. This presumes, of course, that institutional complementarities exist and are of profound significance. While there may be some controversy around this assumption, there is a wide basis of belief in the comparative political economy literature that complementarities matter and exist. A common definition of complementarity is that of Hall and Soskice (2001, 17) who, following Aoki (2001), see complementarity as when "...the presence (or efficiency) of one [institution] increases the returns (or efficiency of) the other." What is common to these and other conceptions of complementarity is the core idea that the coexistence of two (or more) institutions together affects the strategic choices of actors and/or will enhance the ability of actors to achieve their objectives (which may include many objectives, not just maximizing economic gains). Indeed, it is the very existence of complementarity that makes the whole notion of distinct systems or models of capitalism plausible, since complementarity presumes that there are a limited number of ways to combine institutional elements successfully. 
If complementarities enhance actors' capacities (or increase returns to them) then we can readily assume that the institutions that create complementarities will be all the more resistant to change, i.e., any pattern of institutional change will be influenced by the desire of actors to maintain (or obtain) the institutions that generate complementarities. A well-developed theory of complementarity, then, should generate predictions about patterns of institutional change in national economies. There are as yet few such theories. One exception is the theory of Hall and Soskice (2001). Their theory, which divides advanced capitalist economies into two primary types - coordinated and liberal market economies - predicts (in simplified terms) that when confronted with pressures for change, liberal market economies will get 'more liberal' and coordinated market economies will resist liberalization in order to sustain complementarities. More recent work on path dependency theory (e.g., Pierson 2004; Mahoney 2000; North 1991) also argues that the existence of complementarities among institutions inhibits change, i.e., reinforces a given institutional path by generating increasing returns to actors. In this case complementarity leads to predictions not of specific outcomes, but of institutional stasis or stability (until overwhelmed by other forces).

While the basic argument of complementarity is appealing and intuitive, in reality its utility for explaining change is less than straightforward. Once unpacked, there are many ambiguities and hidden assumptions within the concept. Moreover, to be truly useful we must make progress in measuring complementarities. Thus this paper has two primary goals. The first is to further unpack and delineate the concept of complementarity and to address the issue of how to measure the strength or 'binding force' of complementarities. This is obviously essential to advancing any theory of complementarities. The second is to assess the utility of institutional complementarities for explaining observed patterns of change in contemporary capitalist systems. In the end, I believe that while institutional complementarities are significant, assessing their causal effect on institutional change is difficult in most instances and ambiguous. A better understanding requires that we embed complementarities within a more general theory of institutional change which takes a broader view of the ways in which institutions interconnect. 


\section{Unpacking the Concept of Complementarity}

Before turning to the issue of measuring complementarities, it is essential to further refine the concept and to differentiate it from other patterns of institutional interaction or linkages that may appear to an observer as complementarity but in fact are not.

Institutional complementarity exists when the performance of an actor (e.g., a firm or national economy) is enhanced by the coexistence or conjunction of two (or more) specific institutions (see Boyer 2005; Höpner 2003). I suggest it would be useful to break complementarity down into two forms:

1. Complementarity in the form of supplementarity in which one institution makes up for the deficiencies of the other (i.e., provides a "missing ingredient"), thus raising the returns to actors from the first institution (Crouch 2005). ${ }^{1}$ For example, when strong familial social support networks offset the vicissitudes of a highly liberalized labor market. In such cases the existence of the former make the latter more socially and politically acceptable, thus allowing the society to gain the advantages of a liberal labor market.

2. Complementarity in the form of synergy. This embodies the mutually reinforcing effects of compatible incentive structures in different subsystems of an economy. Assume a given individual economic actor - such as a firm - operates in many subsystems of the economy; if the incentive structures across these subsystems reinforce particular strategies by that actor, they cohere by a logic of synergy. Estevez-Abe et al $(2001,182)$, for example, write that the resilience of particular welfare production regimes is "reinforced by institutions - collective wage-bargaining systems, business organizations, employee representation, and financial systems - that facilitate the credible commitment of actors to particular strategies, such as wage restraint and long-term employment, that are necessary to sustain cooperation in the provision of specific skills." Complementarity in the form of synergy may arise through deliberate strategic coordination by actors across institutional domains - Aoki (2001) calls this 'strategic complementarity' - or it may arise through a process akin to evolutionary (functional) selection or co-evolution

\footnotetext{
${ }^{1}$ Crouch actually considers this the true definition of complementarity, but to avoid confusion I will use the term supplementarity to indicate this type of complementarity.
} 
(see also Streeck and Yamamura 2001; Boyer 2005). Thus even where subsystems may not create mutually reinforcing incentive structures, subsystem similarity may develop because it precludes possible reductions in institutional efficiency through negative feedback or externalities from other institutions operating on different principles (see also Whitley 1999, 41).

Institutional coherence refers to a situation in which institutions share common or identical principles, which may facilitate interaction among actors operating under them. Yet this does not necessarily improve measurable performance. Thus coherence may or may not create complementarity (see also Amable 2003: 6-7). Nor is coherence a necessary condition for complementarity, as the notion of supplementarity reflects a situation of incoherence leading to complementarity. Coherence may emerge through a process of isomorphism, as actors adopt similar approaches or institutional solutions to different spheres of action. It might also result from an expansion of a 'logic of appropriateness.' For example, Vitols (2001) argues that to the extent 'shareholder value' as a norm for corporate management is spreading in Germany, it is doing so to a great extent following this logic. Streeck (2005) makes several arguments as to why such isomorphism can be expected.

Institutional compatibility exists when a set of institutions are stable but without being coherent or complementary. In other words, their coexistence does not undermine or weaken the performance of the other but neither does it enhance the other in any way.

Boyer (2005) also highlights institutional clustering, in which two or more institutions are frequently observed together across a larger set of case comparisons. Clustering might well reflect the effects of complementarities but not necessarily, since some clusters may be relatively inefficient. Jackson (2004), for example, uses Ragin's (2000) QCA (Qualitative Comparative Analysis) approach to examine a series of labor relations and corporate governance institutions across OECD countries. Of all the possible permutations, he finds only a limited number of configurations or clusters exist.

Finally, we might also want to consider "a-complementarities" or what Jackson refers to as 'institutional tensions.' This refers to a situation in which institutions within different domains evolve along different logics of coordination, thus creating tensions (confusion, uncertainty) for actors and undermining positive complementarities. If such negative 
complementarities exist, then they could be expected to offset the positive complementarities and reduce aggregate performance measures.

\section{Measuring Complementarities}

If the concept of complementarity is to be truly useful, then we must tackle the issue of metrics. There is no easy answer to the question of how to measure the strength of complementarities. Indeed, I think there is no single answer to this question, as it will depend upon the theory of complementarities one adopts which in turn specifics the mechanisms which create complementarity. It will also depend upon a variety of assumptions one makes. For instance, complementarity operates at different levels, ranging from the macroeconomy to individual organizations and small groups of actors operating in distinct domains. It is conceivable that a given institutional arrangement will have strong complementarities for a narrower group of actors in the economy but only have weak complementarity gains (e.g., in terms of improved economic growth) for the economy as a whole (see also Hall and Gingerich 2004). Or, as Boyer (2005) notes, an institutional arrangement that is complementary for firm owners (in that it raises profitability) may not be complementary for workers. In such instances there is no single measure of the strength of the institutional complementarity under study and the existence of complementarity will depend upon a) the referent subject (e.g., firm or nation) and b) the performance criteria one selects. Selecting performance criteria also grows more challenging when the complementarity of interest is social (e.g, trust, cooperation) or political (e.g., power) in nature.

It is important to remember as well that complementarity is a causal effect or outcome. Thus we cannot measure it directly but must rely on causal inference, as we would with any other causal effect. Ultimately the notion of complementarity rests on a counterfactual argument - that in the absence of the presumably complementary institution, then, ceteris paribus, the returns to actors or efficiency gains would be lower. Nonetheless, we have a large variety of methods at our disposal for attempting to measure complementarities, ranging from multivariate statistical tools to comparative case study methods. In the discussion to follow I will suggest that 
different methods may have certain advantages over others, depending upon the level of complementarity one seeks to measure or depending upon one's definition of complementarity. ${ }^{2}$

Finally, one also needs to make an assumption as to whether complementarity is a continuous or dichotomous variable (see also Amable 2003: 62). If one takes the metric of complementarity to be efficiency gains, then it is in principle a continuous variable (since infinite marginal gains are possible). However, in reality it may be that gains from complementarity must meet a minimum threshold before they matter. Thus, for example, actors may not seek to create or exploit institutions in neighboring domains for only minor efficiency gains, instead requiring some minimum (at least anticipated) return before investing resources in exploiting the potential complementarity. In this case complementarity may take on an essentially binary character either it is there or it is not. In principle one should be able to discern such a condition through empirical investigation. It may also be that our ability to measure complementarities will, in the end, be of a rather crude nature and thus we will, at best, only be able to ascertain with some certainty whether some kind of complementarity exists or does not. In this case it may reflect more a technical limitation than an empirical fact.

Perhaps it is easiest to start with the issue of measuring complementarities at different levels of the political economy. If we start with an economic efficiency or increasing returns conception of complementarity, ${ }^{3}$ then we have some relatively straightforward means to measure complementarities at different levels of the economy. In this case we can utilize any number of performance indicators as our dependent variables. At the macro level, we can attempt to measure complementarities utilizing measures such as productivity gains, innovation rates (e.g., patents) or GDP growth. At the micro level - that is identifiable groups of actors within the economy (e.g., firms or sectors) - we can use profitability, revenue growth, etc. (for example, Milgrom and Roberts 1995).

Hall and Gingerich (2004) have made an excellent first effort to measure the aggregate effects (macro level) of institutional complementarities by correlating institutional configurations with performance measures (mostly GDP growth) across OECD countries (while holding rival explanatory variables constant). Using the core institutions identified in the varieties of

\footnotetext{
${ }^{2}$ Boyer (2005) provides an excellent and detailed assessment of alternative methods and their suitability for measuring complementarity and related concepts of institutional linkage.

${ }^{3}$ For more discussion of complementarity as increasing returns and its connection to path dependence, see Deeg (2005).
} 
capitalism (Hall and Soskice 2001) approach, their study found a clear and internally-consistent clustering of economies into CME and LME types, along with some in the mixed category. These were then correlated with GDP growth over the past two decades and, consistent with the predictions of VOC, economies with high levels of internal institutional consistency - i.e., exhibited the institutional patterns argued to generate complementarities - exhibited higher growth rates than those with lower consistency. In other words, the more "pure” a system was (whether LME or CME), the better it performed, presumably as a result of the complementarities (some other possible causal variables were controlled for).

Another approach to measuring complementarities at the macro level is demonstrated by Boyer (2004). Boyer uses a boolean approach to assess the association between various institutional features and selected macroeconomic performance measures (most importantly total factor productivity). Applying this approach to a range of OECD countries, Boyer identifies three successful combinations or clusters (out of many more theoretically possible permutations) of institutional features that produce superior macroeconomic outcomes. For one of these combinations (the 'knowledge-based economy), he argues that "the common feature is clearly the systemic complementarity between the coordination mechanisms governing the creation and diffusion of knowledge” (Boyer 2004, 15). In contrast to Hall and Gingerich, who treat complementarity as a continuous variable, Boyer's method treats it as dichotomous or binomial variable - it either exists or it does not.

However, while these are impressive efforts to measure the strength (or at least existence) of complementarities, they are still insufficient. First, there are undoubtedly other factors that affect macroeconomic performance and not all of these are controlled for in these studies. This is manifestly obvious in Hall and Gingerich's diachronic test of complementarities in which they find a weakening correlation between institutional complementarities and growth over time without any measured changed in the complementarities themselves (since they are not measuring complementarities directly, only inferring their existence and positive effects). The authors are pressed to explain declining complementarities when the institutions which they believe generate these complementarities have not, in their view, undergone major change. While Hall and Gingerich resort to ad hoc explanations, Paunescu and Schneider (2004) provide systematic evidence showing that many of the institutions examined by Hall and Gingerich have, in fact, changed quite substantially in many advanced economies. Specifically they show a 
widespread movement among economies from coordinated to liberal market institutional arrangements. On the one hand, this is consistent with the Hall and Gingerich (and Hall and Soskice) theory of complementarity, as it explains the decline in measured performance (complementarity) as a result of institutional change. On the other hand, it contradicts the theory's prediction that coordinated economies will resist liberalization in order to sustain the complementarities from which they benefited.

Secondly, these aggregated or macro approaches do not tell us anything about the relative strength or importance of the specific mechanisms of complementarity that operate at the micro level. Thus they do not tell us much about which institutional complementarities are stronger/more important than others. In other words, we do not know if the aggregate effects stem equally or not from complementarities between, say, corporate governance and industrial relations, or between corporate governance and the education and training system. A review of the literature reveals that there is a diversity of opinion within the field over which set of institutions or institutional domains are likely to exhibit complementarities that matter most to enhancing aggregate performance (see Amable, 2003: 93-102). This distinction is obviously important if we want to explain patterns of change within and across these different institutional domains and we assume that the existence/strength of various complementarities plays a role in these processes.

Third, the macro approach generally obscures whether the institutions that generate complementarities might evolve or change over time; or whether existing institutions have been replaced by new ones, while still generating complementarities at the macro level. For example, complementarities at the macro level might be sustained over time by micro level institutional changes that are transitory. Simply focusing on the aggregate level would mislead us into believing in the robustness of the underlying institutional configuration while, in fact, it is changing in ways that will ultimately undermine complementarities. As Boyer (2005) notes, complementarity between a given set of institutions is likely to be context dependent, i.e., other institutions, norms, etc. may be essential antecedent conditions. For example, an insider system of corporate governance may well have been complementary with relational banking in a context of low mergers and acquisitions among firms, but in an era when mergers are abundant, these institutions may no longer be complementary because they inhibit the issuance of shares and a 
high share price that can be used to acquire other firms. In sum, knowing the micro story better will obviously help advance a theory of complementarity.

The other gap left by the macro approach is knowledge about sectoral differences in complementarity. It is easily argued that some sectors within a given economy may profit from extant institutional complementarities while others may not. For example, in the coordinated market economies of Hall and Soskice' schema, the machine tool sector seems more likely to gain than does the software sector, since the former relies on the incremental innovation favored by strategic coordination and the latter typically does not. The macro approach just tells us the sum of complementarities across all firms/sectors, not its distribution. Knowing whether the complementarities are concentrated in some firms/sectors may be vital knowledge for understanding change, for policy prescriptions, and identifying the vulnerabilities of the system as a whole to shocks. We therefore need to supplement these macro approaches with studies of the sources of complementarity at the micro level.

\section{Assessing Complementarities at the Micro level}

In this paper I suggest we consider measuring complementarity at the micro level along three dimensions. The first is to identify and assess the specific institutions which generate complementarities and attempt to assess or measure their respective strength. The second is to assess by sector the strength of complementarities. The third is to assess by the type of complementarity. Some specific methods employed might be a quantitative analysis ala Hall and Gingerich, a comparative case study analysis, or a Boolean analysis ala Boyer.

\section{Measuring by Institutions}

It we take institutions first, there are two levels which we need to study. ${ }^{4}$ The first is the relative significance within a given domain (e.g., industrial relations) of specific institutions (e.g., wage bargaining institutions) for generating complementarities with other domains. The second is to assess the relative importance of complementarities created between domains or

\footnotetext{
${ }^{4}$ Here I follow Aoki (2001) and Amable (2003) in taking the definition of an institution as an endogenously determined rule for social interaction; though there are other valid conceptions of institutions.
} 
spheres. In other words, do the complementarities generated between corporate governance and industrial relations contribute more to aggregate economic performance than the complementarities between the industrial relations system and the training system?

On the first level, taking Hall and Gingerich again, in assessing complementarities between labor relations systems and corporate governance they identify specific institutions shareholder power, dispersion of control, stock market size, level and degree of wage coordination, and labor turnover - that are predicted by their theory to generate complementarities. ${ }^{5}$ In the case of CMEs they posit that complementarities arise when existing institutions facilitate credible commitments by actors to long-term strategies and strategic coordination. In particular the more institutions facilitate four capacities - information exchange, monitoring, sanctioning, and deliberation - the stronger the complementarity that exists. There are two empirical questions here, then, the first is whether the institutions they specify are actually the ones to create complementarity? For example, the VOC perspective posits that bank monitoring of firms facilitates 'patient' capital. But if bank monitoring were removed, another institution such as concentrated ownership may in fact be sufficient to maintain complementarities. Until we can answer such questions we do not in fact know exactly which institutions - or combinations of institutions - within a specific domain are actually responsible for generating complementarities with other domains. Moreover, it is also plausible that within a domain specific institutions might diminish, be replaced or supplemented by other institutions over time yet still maintain the complementarities measured at the macro level.

The boolean approach employed by Boyer might be a good method for this issue. One could, for example, devise a study that codes economies on the level of bank monitoring, ownership concentration, sources of corporate finance, etc. and then code them according to success or non-success on performance measures. The Boolean approach would identify which of the specific institutions (monitoring, concentration) actually seem essential to performance success. Jackson's (2004) study actually takes the first step in this direction: He uses a Boolean approach (QCA) to identify common clusters of corporate governance institutions (inter alia, dispersion of ownership, investor rights, accounting rules, market capitalization, mergers and

\footnotetext{
${ }^{5}$ Most of these are actually structural conditions, but each is a concrete manifestation of many concrete specific institutions, including both formal (codified) and informal institutions. One could take the study down to this level as well.
} 
acquisitions) and labor institutions (employee representation in boards of directors, employment protection law, centralization of collective bargaining, and rate of corporate downsizing). His study finds a more diverse range of coherent institutional clusters than posited by the strict dichotomy of Hall and Soskice. This implies that a wider range of institutional combinations are capable of generating complementarities. Measuring actual complementarities would require the next step which is to correlate the observed clusters with performance outcomes.

Returning to Hall and Gingerich, the second question is how do we assess or measure these four capacities? The last question is essential because it gets at the actual causal mechanisms underlying the theory - e.g., is the act of monitoring by one actor of others that which actually facilitates their coordination and credible commitments? Ultimately one should be able to demonstrate and measure the extent to which actors exchange information, monitor, sanction, etc. and then demonstrate that this enhanced efficiency. Thus it is a two-step process; first establishing that the causal mechanisms are actually operating as hypothesized and then measuring the complementarity they generate.

It seems to me that the best method for assessing monitoring, sanctioning, information exchange etc. is through careful case studies of firm behavior over time. For example, bank monitoring can be assessed via numeric indicators such as corporate board seats held by banks combined with studies of bank intervention in other firms. Fortunately in most OECD countries there already exists a large body of such studies, though undoubtedly there are gaps that would require further research. Assessing the complementarities generated by this behavior could potentially be done through intra-sectoral comparison among firms. This would allow one to control for sectoral effects while comparing firms that are highly engaged in monitoring networks, etc. vs. those that are not (or firms that are members of employers association and engage in wage coordination versus those that are not). If these behaviors exist and generate complementarities, this should be evidenced in superior performance outcomes specified in the particular theory of complementarity (i.e., which activities or capacities are supposedly enhanced), whether this be revenue growth, productivity, innovation, or profitability.

Measuring complementarities in LMEs at the micro level is more difficult, since market coordination among firms does not leave the same trail of evidence as does strategic coordination: the latter is visible in institutions such as industrial associations, inter-firm collaboration, and co-determination. The degree of market coordination is perhaps best indicated 
by the absence of coordination mechanisms among firms, but measuring the 'invisible hand' is a bit tricky. One approach might be to find cases to compare firms within a sector that fully utilize market dynamics and those that attempt to engage in strategic coordination with other firms and see which group performs better. If firms can follow a more coordinated, strategic approach with equal success it would suggest that there are no clear-cut advantages (i.e., complementarities) in market coordination - at least at this level; it could still be that at the macro level such a mixed system would not exhibit the same level of performance/complementarities as more ‘pure’ systems.

The second level at which we may attempt to assess institutional complementarity is the relative importance of different institutional domains. Are complementarities between corporate governance and industrial relations more important to overall economic performance than, say complementarities between labor relations and the training system. One of the difficulties with attempting to make such a measurement is that it may be hard to get enough variation on these variables, since strategic or market coordination tends to be uniform across domains within a given economy. If this is true, quantitative approaches are not likely to work well. Some possibilities to explore this level, however, do exist. For example, in Germany corporate governance has arguably become more market oriented while the industrial relations system remains coordinated (Beyer 2002; Beyer and Höpner 2003). If, then, it can be shown that the demise of coordination within corporate governance has not diminished firm performance it would be an indicator that either there were no complementarities to begin with, or that the complementarities that existed did not arise from the presumed institutions fostering monitoring, etc., or possibly that complementarities have been recreated through new institutions.

\section{Measuring by sectors}

It also seems beneficial to investigate sectoral differences that may arise within economies. There are several reasons for this. One is that firms in some sectors are more likely to rely on strategic coordination and thus enjoy stronger gains from complementarities. In coordinated market economies, for example, retailing seems far less likely to benefit from a coordinated training system than the auto sector, since the former requires relatively modestly skilled labor and the latter relies more on skilled labor. If this were the case, then if the economy were to shift away from sectors like auto toward retailing a pure macro approach might measure 
declining aggregate gains from complementarity when in fact those complementarities still remain equally strong for the auto sector. Thus declining macro performance would result not from declining complementarities but a shifting composition of the economy. Hall and Gingerich invoke just such a scenario as a possible explanation for the declining complementarities they observe over time $(2004,30)$. Knowing which sectors benefit from complementarities and by how much also has obvious import, among other things, for policymakers concerned with overall growth.

Another possible scenario is that firms in one sector begin shifting their strategies toward more market orientation (say banks). A turn towards a market orientation within an otherwise coordinated system would presumably reduce institutional complementarities, but this may be hidden if overall performance measures do not decline. Sectoral analysis can also be defined and examined not by product or service sector but by firm size. There are ample reasons to believe that institutions which generate complementarities for large firms may not do so (or not to the same degree) for smaller firms (see also Paunescu and Schneider 2004). Or, a set of institutions which generates complementarities for large firms will require the presence of other institutions in order to generate similar complementarities for small firms. For example, the combination of strong unions and centralized wage bargaining systems that limit wage spread works to the advantage of large firms but not for smaller firms - unless the latter category is somehow otherwise compensated through other institutions.

\section{Measuring by type of complementarity}

Measuring by type of complementarity may also have some advantage if one kind is generally or systematically stronger or weaker. Intuitively it seems that complementarity in the form of supplementarity would be a dichotomous variable, i.e., if a supplementary institution exists the complementarity is present. Complementarity as synergy, on the other hand, would require measuring a continuous variable since synergy suggests incremental performance improvements can be expected. Thus each of these different types of complementarity might also be suitable to different measurement methods. Crouch (2005) has proposed an approach for assessing supplementarity using an essentially Boolean approach to assess the existence of actor capacities in a given domain, and then ascertaining whether other capacities not present in this domain yet potentially (or occasionally) useful to actors in the first domain are available in other 
domains. Thus actors can potentially tap into such capacities when the need arises, in turn producing positive complementarities. This too would at least initially require a series of cases studies and a deductive theory to postulate and establish the presence of different capacities in different domains. With sufficient number of cases, it may be possible to measure quantitatively the performance gains from this type of complementarity. I have already discussed at some length the measurement of complementarities arising from synergies through performance metrics; this type of complementarity is suitable to quantitative and Boolean analysis.

Measuring tensions or a-complementarities is tricky: It would be difficult to discern between a situation of weak to moderate complementarity between two domains and a situation of strong complementarity between two domains but the measurement of which (if we simply look at aggregate performance data) is lower because the strong complementarity is offset by an acomplementarity. Nonetheless, it is exactly this that must be done in order to identify and measure the strength of an a-complementarity. More likely though, I think this type of complementarity may be too difficult to measure but also not that important to measure, since we are more interested in assessing positive complementarities.

\section{Complementarity and Institutional Change}

On its own the concept of complementarity gives us important insight into a key source of institutional functionality and the genesis of system-ness itself. If, indeed, complementarities among institutions are as common as widely presumed, then our theories of institutional change should also recognize this. But how useful is the concept of complementarity for understanding institutional change? To be useful for theories of change, the concept of complementarity should lead to testable hypotheses regarding change. Here I identify five possible hypotheses suggesting how the existence of complementarities should - or could - affect the process of institutional change. These general hypotheses can inform or serve as the basis for specific hypotheses regarding the set of cases studied.

1. The most obvious and clear hypothesis is that if complementarities among institutions exist, then change in one institution should precipitate change in complementary institutions. If one also subscribes to the concept of institutional hierarchies (e.g., Boyer 
2005, Amable 2003), ${ }^{6}$ then this knock-on effect should be even stronger if the change occurs in the hierarchically dominant institution or institutional domain. However, if hierarchies exist, then changes in subordinate institutions or domains should have little or modest effect on the dominant institution and more generally the whole set of complementary institutions. This hypothesis does not predict the direction of change, i.e., the secondary responses to the initial change may restore the prior functional complementarity, or they may constitute a shift in the whole system to new complementarities.

2. The stronger the complementarities among a set of institutions, the more likely those institutions are to remain stable. This hypothesis rests on the assumption that actors will actively resist changes to the institutions that deliver increased returns or functionality to them. Actors will only support institutional change if the potential payoff (weighted for the anticipated certainty of achieving) from an alternative institutional system is relatively high. This hypothesis is strongly represented in the work of Hall and Soskice (2001; see also Hall and Gingerich 2004; and Schmidt and Spindler 2002).

3. If central coordination of actors engaged in changing a complementary set of institutions is absent, change in one or more of the institutions will undermine (weaken) complementarity (functionality gains) of the system as a whole. This hypothesis rests on the presumption that institutional change resulting from adaptations by individual actors will be unlikely to coordinate with adaptations being made by other individual actors in a manner that sustains optimal complementarity. In other words, individual maximization (adaptations) is unlikely to lead to collective maximization (optimal functionality/complementarity) in the absence of a central coordinator (see Milgrom and Roberts 1995). If this hypothesis is valid, it also suggests another reason why changing institutional systems with strong complementarities will be difficult - the lack or weakness of a central coordinator. At the micro level of an individual firm, it is easier to imagine that a central coordinator (e.g., management) can coordinate change across the set of institutions that generate complementarities for it. However, if we move to the

\footnotetext{
${ }^{6}$ Hierarchy here suggests that in capitalist economies one institutional domain - such as finance - imparts its particular institutional logic to other domains of the economy; thus if finance, for example, is dominant, then a market-oriented financial system would impose or induce greater market orientation in other institutional domains.
} 
macro level, it is equally easy to imagine the difficulty of coordinating change (see also Streeck 2005; Boyer 2005). Even in a highly autocratic political system coordinating change is not likely to be easy.

4. In a system of complementary institutions, once change begins, the upward (strengthening of complementarities) or downward (weakening) movement tends to continue. This hypothesis derives from the notion of complementarity as 'supermodularity,' i.e., when raising the value of one variable (institution) raises the returns to increasing the value of a complementary variable (institution) (see Milgrom and Roberts 1995). In this case complementarity means increasing returns leading to a self-reinforcing process (as is often found in certain theories of path dependency). Thus once change is introduced into the set of complementary institutions, self-reinforcing processes will strengthen that direction of change unless otherwise counteracted.

5. If complementarities are strong, then actors promoting change from one system to another must achieve a critical mass of change across the relevant set of institutions within a relatively short period of time if the change effort is to succeed (see Schmidt and Spindler 2002; Milgrom and Roberts 1995). This draws from the argument that actors will accept temporary reductions in complementarities (functionality) if they believe that the new, superior system will be in place within an acceptable time period. If change is too slow and piecemeal (the typical pattern when change involves political processes), actors are more likely to abandon the effort to move from one system to another. An example of this might be taken from contemporary efforts in Europe to transform corporate governance systems from continental 'insider' systems to Anglo-Saxon 'outsider' systems. Many countries have altered or shifted elements/pieces of their corporate governance system, but few have shifted all; accordingly the process and direction of institutional change in many cases remains ambiguous and politically contested.

How one utilizes the concept of complementarity in explaining institutional change, i.e., approaches these five hypotheses, is determined most importantly by which general model of institutions and institutional change one adopts. Simplifying a bit, there are presently two basic approaches to institutional change within the institutionalist literature (see Streeck and Thelen 
2005 for more discussion): The first approach I will call the equilibrium-functionalist and the second, the historical-political. The equilibrium approach characterizes rational choice institutionalism and also most path dependency theories. In this approach institutions represent self-enforcing equilibria. Both theories see institutions as representing equilibria that change only as a result of exogenous shocks. Thus these theories see institutional change as occurring through breakdown and replacement (“punctuated equilibrium”) of institutions. ${ }^{7}$ In this approach complementarities often help stabilize an equilibrium: A competitive environment among institutions means that those institutions which do not generate complementarities for others are selected out of the environment (Morgan 2005). However, once the institution breaks down complementarities are likely to matter less since change is now underdetermined by definition. If change is conceptualized as breakdown, then complementarity's role in institutional change is less in representing the constraints of the past (i.e., actors trying to sustain complementarity or constrained in their choices by a desire to maintain existing complementarities) than in actors trying to achieve new complementarities. In other words, once an institution breaks down the old complementarities no longer matter. Complementarities matter insofar as actors attempt to design new institutions that will generate new complementarities. In this approach complementarities are analytically central and relatively straightforward in their effects.

A good example of this approach is provided by Hall and Soskice (2001). They hypothesize such strong complementarity that systemic transformation of advanced capitalist systems is very unlikely, even under conditions of Europeanization and globalization. This view allows for two possible patterns of institutional change, either marginal institutional change but not a fundamental change in the underlying logic or character of economic models, or wholesale change in the system - there is no viable middle ground. The latter scenario comes into play if one subsystem, say the financial system, is so radically altered (breaks down) that - because of strong complementarity - it brings on radical institutional changes in other subsystems in order to establish new institutional equilibriums and complementarities. Working in this paradigm, Vitols (2004), for example, reviewed changes in the German financial system and argued that despite a wide range of institutional reforms and changes since the late 1980s, these are largely

\footnotetext{
${ }^{7}$ Though Greif and Laitin (2004) have recently attempted to develop a theory of endogenous change within an equilibrium framework.
} 
marginal changes and the financial system broadly retains its prior character and role in the economy. This stability is argued to result from institutional complementarities with other subsystems - primarily, the structure of the public pension system - that inhibit a deeper transformation of the financial system.

The second, historical-political approach, eschews equilibrium analysis and conceives of institutions (and 'equilibriums') as continuously evolving in non-trivial ways. This approach sees institutions as more or less constantly changing; in many instances smaller or gradual changes add up over time to major institutional transformation (e.g., Streeck and Thelen 2005; Thelen 2004; Morgan 2005; Pierson 2004). There are a number of mechanisms through which gradual change can lead to major transformation. A central avenue for gradual transformation is the gap that arises between the behavior prescribed by rules (i.e., institutions) and actual behavior under that rule/institution. Actors exploit this gap by acting in self-interested ways that typically lead to a reinterpretation or modification of the rule/institution. Sometimes the reaction to actor deviation from the rule is to strengthen or restore the original rule/institutions; sometimes the reaction moves the rule/institution in a new direction (Streeck and Thelen 2005).

In this approach complementarities are likely to matter a lot in shaping institutional change (since actors' behavior is motivated by a desire to increase their own gains), but not in ways easily measured or usable for predicting the direction of change. This is so for several reasons: First, if the exact meaning of a rule/institution is always subject to some interpretation or manipulation, then the complementarity(-ies) that derive from that institution are also somewhat ambiguous. In other words, the effects of institutions are often either ambiguous or not what was originally anticipated at their inception. Thus actors may ignore complementarities because they do not believe they can be reliably assessed (measured) or they are frequently shifting at unanticipated moments. Second, this approach tends to view complementarities as evolving (or changing) through an evolutionary, trial and error process rather than by a one-off moment of institutional (intentional) design, as is typically assumed in the equilibriumfunctionalist approach. Thus complementarities among specific institutions are viewed as historically constituted and variable (i.e., context dependent) and do not have universal characteristics of applicability (see Morgan 2005). Institutions, in this view, also do not simply reflect an economic logic or functionality but also serve other social purposes and embody relations of power and authority as well. Change in such institutions is thus guided also by 
forces other than efficiency gains (or preventing efficiency losses). Thus even where one might adequately measure the complementarity of an institution in functional or performance terms, one cannot predict change based on this alone. Even institutions that are strongly complementary in a functional (economic) sense may change as a result of a shift in power among actors or social norms, not declining functionality. Efforts by actors to pursue their own optimal situation in response to environmental change may also undermine complementarities for other actors.

These two perspectives also lead to different views on how to measure complementarities and, more importantly, how important such efforts are for understanding change. Scholars within the equilibrium-functionalist perspective are more likely to focus on quantifiable complementarities and performance criteria such as innovation, profits, growth, etc. Quantitative assessments have the value of revealing the costs (and potential benefits) of institutional change. Knowing these costs, in turn, can inform predictions about the likelihood of change based on the difference between expected gains from change versus the switching costs (which are a function of complementarities, among other things). While there are clear benefits to such an exercise, the limitations are also clear. First, even where complementarities can be readily inferred from quantitative analysis, as one attempts to measure complementarity among more than two institutions it becomes technically very complex (Boyer 2005). Second, a simple toting up and comparison of relative costs and gains from institutional change is unlikely by itself to yield reliable predictions of change. Even within the assumptions of this perspective, actors' assessment of all costs and benefits are unlikely to be captured by any model. Third, a given set of institutions may generate varying levels of complementarity for different sets of actors measuring the complementarity for one set may well be misleading then.

To this list the historical-political perspective argues the fact that institutions not only have functional performance effects (complementarities) but also social and political effects and these too factor into an analysis of change, yet are often harder to measure quantitatively. Social effects, when translated into measurable performance criteria that would assess the value of the complementarity they generate, might include 'normative coherence,' appropriateness, or trust (enhancement). Political effects or complementarities could be defined on narrow measures like votes, but this is limited since for political actors complementarity is more likely to be measured in terms of their power effects (or, more easily assessed, effects on resources that translate into 
power) or policy outcomes (i.e., their preferred outcome) or policy efficacy. These latter criteria are often not easily quantified. For example, in Germany the institution of worker codetermination on company boards appears to be complementary - from the union's perspective with the newer institutions of corporate financial transparency because this generates more information (power) for unions to use in negotiating with management but also in the general political arena (see Höpner 2003): Yet the value of this complementarity is not easily quantified.

From the historical-political perspective, the 'snapshot' approach of the equilibrium perspective misses the point - it assumes the complementarities are static for a given set of institutions - but if institutions as constantly evolving, so too are the complementarities. This suggests that 'measuring' complementarity is likely to be possible (only) post hoc, and it cannot be assumed that what was measured at time A continues at time B, even when the institutions in question appear stable. Complementarity more often resides not in the institutions themselves but how people use them - thus formal institutional stability can mask declining (or rising) complementarity from the perspective of different actors. It might also be argued that this perspective suggests that complementarities - while real and significant - are also less useful in understanding institutional change because politics (power), uncertainty, myopia, etc. play a big role in change and these are more unpredictable.

The historical-political critique of the equilibrium approach can be illustrated by returning to the Vitols study discussed above. While Vitols' study is thorough and compelling, it may in part be confusing institutional compatibility or clustering with complementarity. For example, how do we know it is complementarities and not other sources of institutional stability such as sunk costs, coordination costs or embedded interests that are preventing broader changes in the German pension system? As suggested in my prior discussion, to answer this question we would need to measure the binding strength of institutional complementarity in such a case. A quantitative approach is not likely to help, since this is a single case. A cross-national comparison is not likely to work because the particular constellation of institutions and change applies to too few cases. A longitudinal study in Germany would need to isolate changed and stable institutions and try to assess whether institutional changes that deviate from the old model and thus weaken institutional complementarity lead to declining performance. But we would need to identify control variables (alternative explanations) as well as a designated performance measure. Even so, it is hard to see how one could generate a sufficiently large sample size to 
conduct a quantitative study. If this is so, then we are left with qualitative case studies resting (implicitly or explicitly) on counterfactual arguments and formal, game theoretic arguments for complementarity (for example, Amable, Ernst, and Palombarini 2005). The problem with the latter approach is that, while it gives us good theoretical reasons for believing the posited complementarities exist, it does not actually demonstrate or test their existence.

Beyond these research and methodology issues, there are other troubling questions such as how do we know when it is institutional complementarity and not just the normal role that institutions play in shaping actor behavior through the incentives they create? Not every institution is complementary to another just because it affects the behavior of actors in predictable ways. Institutional complementarity requires enhanced performance for someone as a result, such that changing one institution harms the other, i.e., the actors who benefited from the coexistence of these institutions. The question in the case analyzed by Vitols is whether German banks would be better off without the present pension system. If it were truly institutional complementarity in the German system that prevented change, then the banks would actively oppose pension reforms in order to retain the old system because it enhances their performance. But in the current state of affairs the German banking/financial system is not particularly profitable by international standards. The bigger financial institutions in Germany are seeking broader changes and generally prefer to see the development of a large private pension system because this fits better with their corporate strategy to increase assets under management, i.e., they believe it would enhance their performance. Thus the pension system may indeed slow change in the financial system but it is no longer (if it was before) complementary inasmuch as it may be a drag on performance. Perhaps now it is an acomplementarity or institutional tension.

The upshot, in my view, is that we must remind ourselves that institutional complementarity is only one element that affects institutional stability and change. There are other sources of institutional stability and change that do not necessarily reflect complementarity or an effort to obtain or maintain complementarity. Moreover, clustering and coherence may be more common than true institutional complementarity. Why might this be the case? First, institutional complementarity is context dependent: Two institutions may complement each other in one setting but not in another. As Boyer (2005) points out, deposit insurance and prudential banking regulation became complementary in Germany but when transferred to Japan did not 
have the same positive effect: Thus in Germany these institutions appear to be complements, but in Japan only clustered. Second, we know that institutions are dynamic and that complementarity often co-evolves over a period of time (see Streeck 2005; Boyer 2005). Thus even if institutional complementarity can be measured effectively ala Hall and Gingerich, in a period of rapid institutional change how useful is such a snapshot? Further, we know that many political economies are evolving through a process of hybridization and attributing performance outcomes to specific institutions under such conditions is difficult, to say the least. Related to this point is the idea that the level or strength of complementarity between two given institutions (or institutional domains) is a moving target in the sense that actors can learn over time to exploit institutions over time, thus strengthening the complementarity without any formal institutional change. If this is possible, the converse condition is also theoretically possible (Streeck 2005). Boyer (2005) suggests further that institutional complementarities may only be discovered ex post and at the same moment in which they are entering a crisis.

\section{Conclusion}

In this paper I set out to extend the utility of the concept of complementarity by beginning to address approaches to actually measuring it. The first step was to establish the boundaries of the concept by elaborating related concepts of institutional linkages such as clustering, compatibility, and coherence. It is crucial that we be able to recognize these distinct patterns, so as not to see complementarity where in fact something else exists. The paper then reviewed some recent efforts to measure complementarity in a more quantitative fashion. While these efforts are important, for a variety of reasons quantitative approaches are difficult to employ in measuring complementarity. Thus the tool belt must contain a variety of approaches, including Boolean analysis, case study, and game theoretic approaches. The paper further proposed that we attempt to measure complementarities not just at the macro but at the microlevel of the economy; specifically by attempting to measure complementarities at the level of specific institutions, sectors, and by type of complementarity. Finally, the paper related the discussion of measuring complementarity to the issue of assessing institutional change. It was suggested that complementarity, while widely assumed to exist, may be easily overestimated in 
its utility for explaining stability and change. Moving forward requires a better ability to actually measure complementarity as well as to distinguish it from other sources of stability and change.

In the end, however, I believe progress toward measuring complementarity will do much to help answer a variety of important questions currently faced in the comparative study of political economies: How we might account for the repeated observation that major institutional subsystems within national capitalisms are changing at varying rates and to varying degrees, is this a result of declining complementarity or something else? Can one institutional domain undergo substantial change without affecting the complementarities that exist with other domains? If so, how might this be possible? Is complementarity maintained by finding functionally equivalent institutions? Is complementarity maintained or generated from a new source of complementarity, i.e., are new capacities created that are distinct from the old ones that generated complementarity? Does the weakening of complementarities at the micro level precipitate institutional change? If so, under which conditions? 


\section{Bibliography}

Amable, Bruno. 2003. The Diversity of Modern Capitalism. Oxford: Oxford University Press. Amable, Bruno, Ekkehard Ernst, and Stefano Palombarini. 2005. "How do financial markets affect industrial relations: An Institutional Complementarity Approach.” Socio-Economic Review 3(2):311-330.

Aoki, Masahiko. 2001. Toward a Comparative Institutional Analysis. Cambridge, MA: MIT Press.

Bettio, Francesca and Janneke Plantenga. 2004. “Comparing Care Regimes in Europe.” Feminist Economics 10(1):85-114.

Beyer, Jürgen. 2002. “Deutschland AG a.D.: Deutsche Bank, Allianz und das

Verflechtungszentrum grosser deutscher Unternehmen.” Max Planck Institute for the Study of Societies, Working Paper 04/4, March 2002.

Beyer, Jürgen and Martin Höpner. 2003. “The Disintegration of Organised Capitalism: German Corporate Governance in the 1990s.” West European Politics 26: 179-98.

Boyer, Robert. 2005. "Coherence, Diversity and Evolution of Capitalisms: The Institutional Complementarity Hypothesis." CEPREMAP, unpublished mimeo.

Boyer, Robert. 2004. "New growth regimes, but still institutional diversity.” Socio-Economic Review, 2(1): 1-32.

Crouch, Colin. 2005. "Complementarity and Fit in the Study of Capitalisms." In Morgan, Glenn, Richard Whitley and Eli Moen, eds. Changing Capitalisms? Internationalization, Institutional Change, and Systems of Economic Organization. Oxford University Press.

Deeg, Richard. 2001. "Institutional Change and the Uses and Limits of Path Dependency: The Case of German Finance," Max Planck Institute for the Study of Societies, Discussion Paper 01/6, 2001.

Deeg, Richard. 2005. “Change from Within: German and Italian Finance in the 1990s.” In Wolfgang Streeck and Kathleen Thelen (eds.), Beyond Continuity: Institutional Change in Advanced Political Economies. Oxford: Oxford University Press.

Den Boer, Monica. 2002. “Towards an Accountability Regime for an Emerging European Policing Governance.” Policing and Society 12(4):275-290. 
Estevez-Abe, Margarita, Torben Iversen, and Soskice, David, 'Social Protection and the Formation of Skills: A Reinterpretation of the Welfare State,' in Hall, Peter A. and Soskice, David, eds., Varieties of Capitalism: The Foundations of Comparative Advantage (Oxford: Oxford University Press, 2001).

Franzese, Robert J., 2001. "Institutional and Sectoral Interactions in Monetary Policy and Wage/Price-Bargaining.” In Hall, Peter and David Soskice (eds.). 2001. Varieties of Capitalism: The Institutional Foundations of Comparative Advantage. Oxford: Oxford University Press.

Greif, Avner and David D. Laitin, 2004. "A Theory of Endogenous Institutional Change." American Political Science Review, 98(4):633-652.

Hall, Peter A. and Daniel W. Gingerich. 2004. 'Varieties of Capitalism and Institutional Complementarities in the Macroeconomy: An Empirical Analysis.' MPIfG Discussion Paper 04/5.

Hall, Peter and David Soskice (eds.). 2001. Varieties of Capitalism: The Institutional Foundations of Comparative Advantage. Oxford: Oxford University Press.

Höpner, Martin. 2003. "What connects industrial relations and corporate governance? Explaining institutional complementarity.” Socio-Economic Review 3(2):331-358.

Jackson, Gregory. 2004. "Toward a comparative perspective on corporate governance and labour management.” REITI Discussion Paper Series 04-E-023.

Lane, Christel. 2005. "Institutional Transformation and System Change: Changes in Corporate Governance of German Corporations.” In Morgan, Glenn, Richard Whitley and Eli Moen, eds. Changing Capitalisms? Internationalization, Institutional Change, and Systems of Economic Organization. Oxford University Press.

Lieberman, Robert C., 'Ideas, Institutions, and Political Order: Explaining Political Change,' American Political Science Review, 96 (2002), 697-712.

Mahoney, James. 2000. "Path Dependence in historical sociology." Theory and Society, 29: 50748.

Milgrom, Paul and John Roberts, 1995. "Complementarities and fit: Strategy, Structure, and organizational Change." Journal of Accounting and Economics 19:179-208. 
Morgan, Glenn and Izumi Kubo. 2005. "Beyond Path Dependency? Constructing new models for institutional change: The Case of Capital Markets in Japan.” Socio-Economic Review 3(1):55-82.

Morgan, Glenn. 2005. "Institutional Complementarities, Path Dependency, and the Dynamics of Firms.” In Morgan, Glenn, Richard Whitley and Eli Moen, eds. Changing Capitalisms? Internationalization, Institutional Change, and Systems of Economic Organization. Oxford University Press.

North, Douglass C. 1991. Institutions, Institutional Change and Economic Performance. Cambridge: Cambridge University Press.

Paunescu, Mihai and Martin Schneider. 2004. "Wettbewerbsfaehigkeit und Dynamik institutioneller Standortbedingungen: Ein empirischer Test des "Varieties of Capitalism"Ansatzes." Unpublished mimeo, University of Trier.

Pierson, Paul. 2004. Politics in Time: History, Institutions and Social Analysis. Princeton: Princeton University Press.

Ragin, Charles C. 2000. Fuzzy-Set Social Science. Chicago: University of Chicago Press. Schmidt, Reinhardt H. and Gerald Spindler. 2002. "Path Dependence, Corporate Governance and Complementarity." International Finance 5(3):311-333.

Streeck, Wolfgang. 2005. "Requirements for a useful concept of complementarity.” SocioEconomic Review 3(2):363-366.

Streeck, Wolfgang and Kathleen Thelen. 2005. “Introduction.” In Streeck, Wolfgang and Kathleen Thelen (eds.), Beyond Continuity: Institutional Change in Advanced Political Economies. Oxford: Oxford University Press.

Streeck, Wolfgang and Yamamura, Kozo, eds., 2001. The Origins of Nonliberal Capitalism: Germany and Japan in Comparison. Ithaca: Cornell University Press.

Thelen, Kathleen. 2004. How Institutions Evolve: The Political Economy of Skills in Germany, Britain, the United States, and Japan. Cambridge: Cambridge University Press.

Vitols, Sigurt. 2001. "Varieties of Corporate Governance: Comparing Germany and the UK," in Hall, Peter A. and Soskice, David, eds., Varieties of Capitalism: The Foundations of Comparative Advantage. Oxford: Oxford University Press. 
Vitols, Sigurt. 2004. "Changes in Germany’s Bank-Based Financial System: A Varieties of Capitalism Perspective.” Social Science Research Centre Berlin, Discussion Paper SP II 2004-03.

Whitley Divergent Capitalisms: The Social Structuring and Change of Business Systems (Oxford: Oxford University Press, 1999). 

Bücher des Forschungsschwerpunkts Markt und politische Ökonomie

Books of the Research Area Markets and Political Economy

Pablo Beramendi

Decentralization and Income Inequality

2003, Madrid: Juan March Institute

Thomas Cusack

A National Challenge at the Local Level: Citizens, Elites and Institutions in Reunified Germany

2003, Ashgate

Sebastian Kessing

Essays on Employment Protection

2003, Freie Universität Berlin

http://www.diss.fu-berlin.de/2003/202

Daniel Krähmer

On Learning and Information in Markets and

Organizations

2003, Shaker Verlag

Bob Hancké

Large Firms and Institutional Change. Industrial Renewal and Economic Restructuring in France 2002, Oxford University Press

Andreas Stephan

Essays on the Contribution of Public Infrastruc-

ture to Private: Production and its Political

Economy

2002, dissertation.de

Peter A. Hall, David Soskice (Eds.)

Varieties of Capitalism

2001, Oxford University Press

Hans Mewis

Essays on Herd Behavior and Strategic Delegation

2001, Shaker Verlag

Andreas Moerke

Organisationslernen über Netzwerke - Die

personellen Verflechtungen von Führungsgremien

japanischer Aktiengesellschaften

2001, Deutscher Universitäts-Verlag

Silke Neubauer

Multimarket Contact and Organizational Design

2001, Deutscher Universitäts-Verlag

Lars-Hendrik Röller, Christian Wey (Eds.)

Die Soziale Marktwirtschaft in der neuen

Weltwirtschaft, WZB Jahrbuch 2001

2001, edition sigma

Michael Tröge

Competition in Credit Markets: A Theoretic

Analysis

2001, Deutscher Universitäts-Verlag

Torben Iversen, Jonas Pontusson, David Soskice

(Eds.)

Unions, Employers, and Central Banks

2000, Cambridge University Press
Tobias Miarka

Financial Intermediation and Deregulation:

A Critical Analysis of Japanese Bank-Firm-

Relationships

2000, Physica-Verlag

Rita Zobel

Beschäftigungsveränderungen und

organisationales Lernen in japanischen

Industriengesellschaften

2000, Humboldt-Universität zu Berlin

http://dochost.rz.hu-berlin.de/dissertationen/zobel-rita2000-06-19

Jos Jansen

Essays on Incentives in Regulation and Innovation 2000, Tilburg University

Ralph Siebert

Innovation, Research Joint Ventures, and

Multiproduct Competition

2000, Humboldt-Universität zu Berlin

http://dochost.rz.hu-berlin.de/dissertationen/siebert-

ralph-2000-03-23/

Damien J. Neven, Lars-Hendrik Röller (Eds.)

The Political Economy of Industrial Policy in

Europe and the Member States

2000, edition sigma

Jianping Yang

Bankbeziehungen deutscher Unternehmen:

Investitionsverhalten und Risikoanalyse

2000, Deutscher Universitäts-Verlag

Christoph Schenk

Cooperation between Competitors -

Subcontracting and the Influence of Information,

Production and Capacity on Market Structure and

Competition

1999, Humboldt-Universität zu Berlin

http://dochost.rz.hu-berlin.de/dissertationen/schenkchristoph-1999-11-16

Horst Albach, Ulrike Görtzen, Rita Zobel (Eds.)

Information Processing as a Competitive

Advantage of Japanese Firms

1999, edition sigma

Dieter Köster

Wettbewerb in Netzproduktmärkten

1999, Deutscher Universitäts-Verlag

Christian Wey

Marktorganisation durch Standardisierung: Ein

Beitrag zur Neuen Institutionenökonomik des

Marktes

1999, edition sigma 

Jos Jansen

Johan Lagerlöf

Lars Frisell

Sigurt Vitols

Lutz Engelhardt

Antonio Guarino

Steffen Huck

Thomas D. Jeitschko

Thomas Plümper

Vera E. Troeger

Ulrich Kaisera

Pablo Beramendi Thomas R. Cusack Joseph Clougherty

Joseph Clougherty

Anming Zhang

Roel C.A. Oomen

Robert J. Franzese,Jr. Jude C. Hays

Albert Banal-Estañol Inés Macho-Stadler Jo Seldeslachts

Oz Shy

Rune Stenbacka

Jonathan Beck

Michal Grajek

Paul Heidhues Botond Kőszegi

Chiara Strozzi
Partial Information Sharing in Cournot Oligopoly

Lobbying, Information Transmission, and Unequal Representation

Changes in Germany's Bank Based Financial System: A Varieties of Capitalism Perspective

Entrepreneurial Business Models in the German Software Industry: Companies, Venture Capital, and Stock Market Based Growth Strategies of the ,Neuer Markt'

Can Fear Cause Economic Collapse?

Insights from an Experimental Study

External Effects of Currency Unions

An Estimated Model of the German Magazine Market

Diverse Disparities: The Politics and Economics of Wage, Market and Disposable Income Inequalities

Antitrust Holdup Source, Cross-National Institutional Variation, and Corporate Political Strategy Implications for Domestic Mergers in a Global Context

Export Orientation and Domestic Merger Policy: Theory and Some Empirical Evidence

Modelling Realized Variance when Returns are Serially Correlated

Modeling International Diffusion: Inferential Benefits and Methodological Challenges, with an Application to International Tax Competition

Mergers, Investment Decisions and Internal Organisation

Price Competition, Business Hours, and Shopping Time Flexibility

Fixed, focal, fair? Book Prices Under Optional resale Price Maintenance

Diffusion of ISO 9000 Standards and International Trade

The Impact of Consumer Loss Aversion on Pricing

Citizenship Laws and International Migration in Historical Perspective

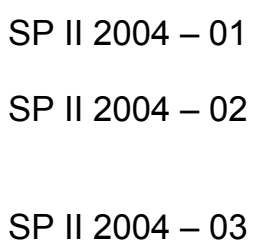


Olivier Gossner

Informational Cascades Elicit Private Information

SP || $2004-19$ 
Lutz Engelhardt

Philipp Rehm

Sigurt Vitols Lutz Engelhardt

Sebastian G. Kessing

Kai A. Konrad

Kai A. Konrad Amedeo Spadaro

Joseph A. Clougherty

Talat Mahmood

Sara Geerdes Klaus Schömann

Johannes Münster

Albert Banal-Estañol Jo Seldeslachts

Kai A. Konrad

Johannes Münster

Oz Shy

Kai A. Konrad Stergios Skaperdas

Kai A. Konrad

Dan Kovenock

Thomas Cusack

Torben Iversen

Philipp Rehm

Tomaso Duso

Klaus Gugler

Burcin Yurtoglu

Dan Kovenock

Brian Roberson

Sebastian G. Kessing

Kai A. Konrad

Christos Kotsogiannis
Geschäftsmodelle und nationale Institutionen: Ein

SP || $2005-01$ Vergleich britischer und deutscher Neuemissionen aus der IT-Service - und Softwareindustrie 1996 2002

Citizen Support for the Welfare State: Determinants of Preferences for Income Redistribution

National Institutions and High Tech Industries:

A Varieties of Capitalism Perspective on the Failure of Germany's "Neuer Markt"

Union Strategy and Optimal Income

Taxation

Education, Redistributive Taxation, and

Confidence

The International Drivers of Domestic Airline

Mergers in Twenty Nations: Integrating Industrial

Organization and International Business

Unmet Labour Demand In Europe - Chances for

Immigrants?

Simultaneous Inter- and Intra-Group Conflicts

Merger Failures

SP || $2005-08$

SP || 2005- 09

Silent Interests and All-Pay Auctions

SP || $2005-10$

Lobbying Contests with Endogenous Policy

Proposals

SP || $2005-11$

SP || $2005-12$

Conversion: Theory and Calibration

Succession Rules and Leadership Rents

SP || $2005-13$

Equilibrium and Efficiency in the Tug-of-War

SP || $2005-14$

Risks at Work: The Demand and Supply Sides of Government Redistribution

SP || $2005-15$

EU Merger Remedies: A Preliminary Empirical

Assessment

SP || $2005-16$

Electoral Poaching and Party Identification

SP || $2005-17$

Federal Tax Autonomy and the Limits of

Cooperation 
Jonathan Beck Michał Grajek

Christian Wey

Ela Glowicka

Richard Deeg
Hypermarket Competition and the Diffusion of Retail Checkout Barcode Scanning

SP || $2005-19$

SP || $2005-20$ Approach

Complementarity and Institutional Change: How Useful a Concept?"

SP || $2005-21$ 
Bei Ihren Bestellungen von WZB-Papers schicken

Sie bitte unbedingt einen an Sie adressierten Auf-

kleber mit sowie je paper eine Briefmarke im Wert

von 0,51 Euro oder einen "Coupon Reponse Inter-

national " (für Besteller aus dem Ausland)
Please send a self addressed label and postage stamps in the amount of 0.51 Euro or a "CouponReponse International" (if you are ordering from outside Germany) for each WZB-paper requested

Absender I Return Address:

Wissenschaftszentrum Berlin

für Sozialforschung

Presse- und informationsreferat

Reichpietschufer 50

D-10785 Berlin-Tiergarten

Hiermit bestelle ich folgende(s)

Discussion paper(s):

Please send me the following Discussion paper(s):

Bestell-Nr. I Order no.

Autor/in, Kurztitel /Author(s) / Title(s) in brief 